\title{
Mucuna gum microspheres for oral delivery of glibenclamide: In vitro evaluation
}

ANTHONY AMAECHI ATTAMA* OBICHUKWU J. NWABUNZE

Drug Delivery Research Unit Department of Pharmaceutics Faculty of Pharmaceutical Sciences University of Nigeria Nsukka 410001, Nigeria

\begin{abstract}
An investigation into the suitability of mucuna gum microspheres for oral delivery of glibenclamide is presented. Mucuna gum microspheres were formulated under different conditions of polymer concentration and crosslinking time at constant speed. The formulated microspheres were thereafter loaded with glibenclamide by the remote loading process. The microspheres were evaluated according to particle size, yield, loading efficiency and swelling. In vitro release of glibenclamide from the microspheres was studied in simulated intestinal fluid (SIF, pH 7.4). The release data was fitted into two release models to investigate the mechanism of glibenclamide release from the microspheres. All the microspheres showed good swelling characteristics in distilled water. The investigation revealed that the microspheres produced with $5 \%(\mathrm{~m} / V)$ mucuna gum with a crosslinking time of $5 \mathrm{~h}$ had the optimum prolonged release pattern. The microspheres produced using $10 \%(\mathrm{~m} / \mathrm{V})$ mucuna gum with a crosslinking time of $1 \mathrm{~h}$ had the highest delayed release of the incorporated drug, whereas those without crosslinking had the fastest release. The Ritger-Peppas case I transport model appeared to have adequately described the release process as about $54 \%$ of the batches of microspheres conformed to this model. This implies that a formulation of glibenclamide-loaded mucuna gum microspheres is likely to offer a reliable means of delivering glibenclamide by the oral route.
\end{abstract}

Keywords: mucuna gum, microspheres, glibenclamide, in vitro release, oral delivery

Microspheres refer to the micro-particulate polymer based drug delivery system with an average particle size larger than $1 \mu \mathrm{m}$. Microsphere carrier systems made from naturally occurring biodegradable polymers have attracted considerable attention for several

\footnotetext{
* Correspondence, e-mail: aaattama@yahoo.com
} 
years (1). They have been formulated as mucoadhesive particles or tablets (1-3). There has been adequate coverage of the microspheres drug delivery system $(4,5)$. Polymeric microparticles represent an interesting drug delivery strategy. They shield the encapsulated drug from the external harsh conditions, prolong drug release and may favour uptake by intestinal cells (6). Many polymers have been used in the formulation of microspheres (7). Biodegradable microspheres break down completely into harmless metabolites that are easily eliminated through natural body functions. Polymers such as chitosan, gelatin, polylactic acids and their derivatives have all been extensively studied for their ability to form microspheres $(4,8,9)$.

The polymer proposed in this work (mucuna gum) is a biodegradable polymer. It was obtained from the plant Mucuna flagillepes (Papillionaceae). It is extracted from the cotyledons. Mucuna gum is amorphous, insoluble in alcohol and swells to a viscous mass in water. Mucuna gum is edible and no adverse toxicological effect of the gum has been reported. It contains D-galactose as the major monosaccharide with the presence of D-mannose and D-glucose and has been evaluated for use as a food additive (10). In the pharmaceutical arena, mucuna gum has been shown to be a good suspending agent and stabilizer in suspensions and emulsions, a good binder in compressed tablets and a good motif for bioadhesive drug delivery (11-14). The film properties of mucuna gum have been studied as well (15). Glibenclamide, a second generation sulphonylurea is an orally bioavailable hypoglycaemic agent used in the management of type II diabetes. The objectives of this study were to formulate mucuna gum microspheres containing glibenclamide, characterize the mucuna gum microsphere delivery systems, and evaluate the in vitro release characteristics of glibenclamide from such a delivery system.

\section{EXPERIMENTAL}

\section{Materials}

Materials used include glibenclamide (Pfizer, Nigeria), gelatin, glutaraldehyde and sodium hydroxide (Merck, Germany) and olive oil (B.P. grade). Other reagents and solvents were of analytical grade and were used without further purification. Mucuna seeds were locally acquired from Nsukka market.

\section{Methods}

Extraction of mucuna gum. - Mucuna seeds were roasted at $70{ }^{\circ} \mathrm{C}$ for $10 \mathrm{~min}$ to make the shell brittle. The seeds were then dehusked and the cotyledons were autoclaved in a $1 \%(\mathrm{~m} / \mathrm{V})$ solution of sodium metabisulphite at $121{ }^{\circ} \mathrm{C}$ for $15 \mathrm{~min}$. This helps inactivate the enzymes usually present and also reduces darkening. The cotyledons were then air-dried, pulverized in a hammer mill and the flour obtained was soaked in a solution of $1 \%(m / V)$ sodium metabisulphite for $24 \mathrm{~h}$ and thereafter passed through a muslin cloth. The resultant filtrate was desolvated with acetone. This product of desolvation (mucuna gum) was dried in a hot air oven (Model OV110, Gallenkamp, Germany) and then pulverized. 


\section{Preparation of microspheres and characterization}

Mucuna gum microspheres. - A 50-mL volume of a $5 \%(\mathrm{~m} / \mathrm{V})$ dispersion of the polymer in distilled water was prepared and added dropwise to a beaker containing $50 \mathrm{~mL}$ of olive oil on a stirrer at a speed of $5000 \mathrm{rpm}$. It was stirred for $30 \mathrm{~min}$ at a temperature of $40{ }^{\circ} \mathrm{C}$. A $15-\mathrm{mL}$ volume of acetone was then added and the mixture was further stirred for $30 \mathrm{~min}$. The microspheres were then crosslinked with $1 \mathrm{~mL}$ of a $4 \%(V / V)$ glutaraldehyde solution in acetone $/ 0.01 \mathrm{~mol} \mathrm{~L}^{-1} \mathrm{HCl}$ solution (7:3) for a pre-determined time. The mixture was then centrifuged at a speed of $5000 \mathrm{rpm}$ for $5 \mathrm{~min}$ and the microspheres were recovered. The resulting microspheres were thereafter washed with acetone and dried at $28^{\circ} \mathrm{C}$. Other batches were similarly prepared. Table I shows the formulation variables.

Gelatin microspheres. - A 50-mL volume of a $5 \%(\mathrm{~m} / \mathrm{V})$ gelatin dispersion was prepared, pre-heated to $40{ }^{\circ} \mathrm{C}$ and added dropwise to $50 \mathrm{~mL}$ of olive oil at a temperature of $40{ }^{\circ} \mathrm{C}$ and stirred at a speed of $5000 \mathrm{rpm}$ for $30 \mathrm{~min}$. Acetone was added as above and a 1 $\mathrm{mL}$ volume of glutaraldehyde solution was also added and stirring continued for $1 \mathrm{~h}$. The microspheres were recovered after centrifugation at a speed of $5000 \mathrm{rpm}$ for $5 \mathrm{~min}$. Acetone was used to wash the microspheres and then, they were dried at $28{ }^{\circ} \mathrm{C}$.

Particle size determination and swelling studies. - A $5 \mathrm{mg}$ quantity of the microspheres was placed inside the ring of an internally calibrated microscopic slide (Objective Micrometer, Olympus KS Japan) and a drop of glycerol was added. The slide was covered with a cover slip and viewed under a binocular microscope at a magnification of X100.

Table I. Formulation and physical properties of mucuna gum microspheres

\begin{tabular}{cccccccc}
\hline $\begin{array}{c}\text { Batch } \\
\text { code }\end{array}$ & $\begin{array}{c}\text { Mucuna gum } \\
\text { concentration } \\
(\%, m / V)\end{array}$ & $\begin{array}{c}\text { Cross- } \\
\text { linking } \\
\text { time }(\mathrm{h})\end{array}$ & $\begin{array}{c}\text { Yield } \\
(\%)\end{array}$ & $\begin{array}{c}\text { Swelling } \\
\text { factor }^{\mathrm{a}, \mathrm{b}}\end{array}$ & $\begin{array}{c}\text { Drug content } \\
(\mathrm{mg} \text { per } \\
100 \mathrm{mg})^{\mathrm{a}, \mathrm{c}}\end{array}$ & $\begin{array}{c}\text { Loading } \\
\text { ffficiency,c }^{\mathrm{a}, \mathrm{c}}\end{array}$ & $\begin{array}{c}\text { Size } \\
(\mu \mathrm{m})^{\mathrm{a}, \mathrm{d}}\end{array}$ \\
\hline MGF-0 & 5.0 & 0 & 76.8 & $6.5 \pm 0.9$ & $7.88 \pm 1.21$ & $78.8 \pm 2.1$ & $12.59 \pm 7.12$ \\
MGF-1 & 5.0 & 1 & 88.0 & $5.4 \pm 1.2$ & $8.74 \pm 2.13$ & $87.4 \pm 1.9$ & $17.32 \pm 8.20$ \\
MGF-3 & 5.0 & 3 & 75.6 & $2.9 \pm 1.2$ & $9.96 \pm 1.01$ & $98.4 \pm 3.2$ & $6.25 \pm 1.89$ \\
MGF-5 & 5.0 & 5 & 79.6 & $5.4 \pm 1.1$ & $8.42 \pm 1.42$ & $84.2 \pm 2.3$ & $15.22 \pm 5.99$ \\
MGS-0 & 7.5 & 0 & 57.3 & $5.0 \pm 0.9$ & $7.08 \pm 2.34$ & $70.8 \pm 1.7$ & $42.75 \pm 9.15$ \\
MGS-1 & 7.5 & 1 & 56.0 & $4.6 \pm 1.1$ & $6.16 \pm 3.11$ & $61.6 \pm 2.1$ & $22.57 \pm 9.17$ \\
MGS-3 & 7.5 & 3 & 90.7 & $4.5 \pm 0.8$ & $9.90 \pm 0.97$ & $99.0 \pm 0.2$ & $32.41 \pm 10.43$ \\
MGS-5 & 7.5 & 5 & 48.5 & $6.7 \pm 1.3$ & $8.58 \pm 1.32$ & $85.8 \pm 2.5$ & $13.75 \pm 8.82$ \\
MGT-0 & 10.0 & 0 & 83.2 & $5.5 \pm 0.8$ & $8.12 \pm 0.96$ & $81.2 \pm 1.5$ & $16.25 \pm 9.16$ \\
MGT-1 & 10.0 & 1 & 61.8 & $5.4 \pm 1.1$ & $9.84 \pm 0.76$ & $98.4 \pm 0.2$ & $8.75 \pm 3.39$ \\
MGT-3 & 10.0 & 3 & 76.4 & $4.4 \pm 0.9$ & $9.94 \pm 0.52$ & $99.4 \pm 1.1$ & $13.67 \pm 9.82$ \\
MGT-5 & 10.0 & 5 & 89.2 & $4.7 \pm 1.1$ & $4.56 \pm 2.83$ & $45.6 \pm 4.7$ & $11.28 \pm 5.46$ \\
Gelatin & 5.0 & 1 & 78.4 & $4.5 \pm 1.2$ & $9.00 \pm 1.06$ & $90.0 \pm 2.6$ & $11.52 \pm 7.96$ \\
\hline
\end{tabular}

${ }^{\mathrm{a}}$ Mean $\pm \mathrm{SD},{ }^{\mathrm{b}} n=5,{ }^{\mathrm{c}} n=3,{ }^{\mathrm{d}} n=50$. 
Swelling experiments were repeated five times and the swelling factors were calculated after 60 min swelling.

Drug loading. - A 1000-mg quantity of dried microspheres from each batch was incubated with a solution of glibenclamide $\left[1 \%(\mathrm{~m} / \mathrm{V})\right.$ in $0.1 \mathrm{~mol} \mathrm{~L}^{-1}$ sodium hydroxide] in an incubator for $6 \mathrm{~h}$ at a temperature of $37^{\circ} \mathrm{C}$. The microspheres were removed and dried at room temperature.

Preparation of simulated intestinal fluid (SIF, $p H$ 7.4). - SIF ( $\mathrm{pH} 7.4)$ without pepsin was prepared following the USP standard (16) from monobasic potassium phosphate.

Loading efficiency. - Each $50 \mathrm{mg}$ of the drug loaded microspheres was put in a 25-mL volumetric flask, $0.1 \mathrm{~mol} \mathrm{~L}^{-1}$ sodium hydroxide solution was added to the mark and the content was allowed to hydrate for $24 \mathrm{~h}$ at $28{ }^{\circ} \mathrm{C}$. The solution was filtered, appropriately diluted and then analyzed for glibenclamide content spectrophotometrically (UV-VIS Spectrophotometer, Milton Roy, USA) at $226 \mathrm{~nm}$, which was repeated three times for each batch. This was used to calculate the absolute drug content of the various microspheres. Beer's plot for glibenclamide in SIF ( $\mathrm{pH}$ 7.4) was made at a wavelength of 215 $\mathrm{nm}$ and subsequently used for drug release studies.

In vitro release of glibenclamide. - The magnetic stirrer hot plate assembly was used. A 250-mL volume of SIF ( $\mathrm{pH} 7.4$ ) consisting of the release medium was placed in a 500-mL beaker containing a magnetic stirring rod. This was maintained at $37 \pm 1{ }^{\circ} \mathrm{C}$ with the aid of a thermoregulated hot plate. In each case, $50 \mathrm{mg}$ of drug loaded microspheres was placed in a smaller beaker whose bottom was opened and to which, a mesh of aperture size of not greater than $1 \mu \mathrm{m}$ was attached. This was immersed in the dissolution medium under agitation of $100 \mathrm{rpm}$ provided by the magnetic stirrer. Ten millilitre samples were withdrawn and filtered at pre-determined time intervals from the dissolution medium outside the smaller beaker containing the microspheres. For each sample withdrawn, an equivalent volume $(10 \mathrm{~mL})$ of SIF maintained at the same temperature was added to the contents of the dissolution medium to maintain sink conditions throughout the release period. The samples were thereafter analyzed spectrophotometrically at $215 \mathrm{~nm}$. Two measurements were made for each batch of microspheres.

\section{Release kinetics and mechanism}

Higuchi's square root model (17) primarily describes drug release from a heterogeneous matrix where the drug is dispersed uniformly. It aims to describe the drug release by a combination of drug dissolution and diffusion out of the hydrated or solvated polymer matrix:

$$
F=k_{\mathrm{H}} \sqrt{t}
$$

where $F$ is the percentage of drug released at time $t$, while $k_{\mathrm{H}}$ is the Higuchi release rate constant. A plot of $F$ against $t^{1 / 2}$ gives a straight line if the process is diffusion controlled.

Ritger-Peppas model (18) is often applied to describe drug release from matrix systems of various geometries by using a simple exponential relationship: 


$$
\frac{M_{t}}{M_{\alpha}}=k_{\mathrm{RP}} t^{n}
$$

where $M_{t} / M_{\alpha}$ denotes the fraction of drug released at time $t . k_{\mathrm{RP}}$ is the Ritger-Peppas release rate constant characteristic of the controlled release device and $n$ is the diffusional exponent, indicative of the mechanism of drug release. In spherical matrices, if $n \leq 0.43$, a Fickian diffusion (case I), $0.43 \leq n \quad 0.85$, a non-Fickian transport and $n \quad 0.85$, a case II transport (zero-order) drug release mechanism dominates.

\section{RESULTS AND DISCUSSION}

The particle size distribution of the microspheres is presented in Table I. The mean particle size $(n=50)$ of the microspheres ranged from $6.25 \pm 1.89$ to $42.75 \pm 9.15 \mu \mathrm{m}$. Microspheres formulated with $5.0 \%(\mathrm{~m} / \mathrm{V})$ of mucuna gum and crosslinked for $3 \mathrm{~h}$ had the smallest particle size while microspheres formulated with $7.5 \%(\mathrm{~m} / \mathrm{V})$ of mucuna gum without crosslinking possessed the largest mean particle size. Viewed under a microscope, the microspheres had a spherical appearance except for some batches that appeared to have some degree of hydration, especially those prepared with $7.5 \%(\mathrm{~m} / \mathrm{V})$ mucuna gum. The sizes were all within the lower micrometer range, indicating that the production process was able to achieve the intended end point. There was no direct correlation between the microsphere size and the crosslinking time. It appeared that the average size of the microspheres increased with an increase in mucuna gum concentration, consistent with the earlier report (19). However, the microspheres formulated with $7.5 \%$ $(\mathrm{m} / \mathrm{V})$ mucuna gum had a larger size than other microspheres, especially the uncrosslinked microspheres and microspheres crosslinked for $1 \mathrm{~h}$ and $5 \mathrm{~h}$ because of the partial hydration mentioned above. These microspheres had particle sizes of $42.75 \pm 9.15 \mu \mathrm{m}$, $22.57 \pm 9.17 \mu \mathrm{m}$ and $32.41 \pm 10.43 \mu \mathrm{m}$ respectively. Other batches of microspheres had sizes that were not significantly different from the size of gelatin microspheres, except those prepared with $5.0 \%(\mathrm{~m} / \mathrm{V})$ mucuna gum with $3 \mathrm{~h}$ crosslinking and $10.0 \%(\mathrm{~m} / \mathrm{V})$ mucuna gum with $1 \mathrm{~h}$ crosslinking. Particle size of microparticles/microspheres is a very important parameter, since it affects drug release and pharmacokinetics (20). For microspheres engineered for parenteral administration, large particles will find it difficult to pass through the syringe. However, the microspheres evaluated in this study are intended for oral administration and particle size will influence only the rate of drug release and subsequent pharmacokinetics.

Results presented in Table I show no evidence of correlation between the mass of polymer introduced during formulation of microspheres and the microsphere yield (as well as percentage yield). In all cases, the yield was lower than $100 \%$, both for mucuna gum alone and gelatin (yield 78\%). Particularly noteworthy are the batches that had yields below $60 \%$. This occurred in microspheres prepared with $7.5 \%(\mathrm{~m} / \mathrm{V})$ of mucuna gum, except MGS-3. The reason for their low yield could not be explained.

The microspheres swelled to between two and five times their original volume, with the mircospheres prepared with $7.5 \%(\mathrm{~m} / \mathrm{V})$ mucuna gum and crosslinked for $5 \mathrm{~h}$ pro- 
ducing the highest swelling factor, while microspheres prepared with $5.0 \%(\mathrm{~m} / \mathrm{V}) \mathrm{mu}$ cuna gum with $3 \mathrm{~h}$ crosslinking produced the lowest swelling factor. In comparison with the swelling of gelatin microspheres, all the batches exhibited a good swelling profile except those prepared with $5.0 \%(\mathrm{~m} / \mathrm{V})$ mucuna gum with $3 \mathrm{~h}$ crosslinking. However, the results show that microspheres crosslinked for $3 \mathrm{~h}$ had almost the lowest swelling factor in the batches. This may be the optimum crosslinking time to produce microspheres for the sustained release dosage form.

Table I shows that all the microspheres prepared with mucuna gum showed loading efficiencies not significantly different from microspheres prepared with gelatin, except microspheres prepared with $5.0 \%(\mathrm{~m} / \mathrm{V})$ and $7.5 \%(\mathrm{~m} / \mathrm{V})$ mucuna gum without crosslinking and $10.0 \%(\mathrm{~m} / \mathrm{V})$ mucuna gum with crosslinking for $5 \mathrm{~h}$. The batch containing gelatin as the polymer (standard) had a drug content of $9.00 \mathrm{mg}$ per $100 \mathrm{mg}$ microspheres. Compared with the drug load of gelatin microspheres $(90.0 \pm 2.6 \%)$, the microspheres formulated with 5.0 and $7.5 \%(\mathrm{~m} / \mathrm{V})$ mucuna gum and crosslinked for $3 \mathrm{~h}$ [MGF-3 $(98.4 \pm 3.2 \%)$ and MGS-3 $(99.0 \pm 0.2 \%)$, respectively] and microspheres formulated with $10.0 \%(\mathrm{~m} / \mathrm{V})$ of mucuna gum and crosslinked for 1 and $3 \mathrm{~h}$ [MGT-1 $(98.4 \pm 0.2 \%)$ and MGT-3 $(99.4 \pm 1.1 \%)$ ] had significantly higher mean loading efficiencies $(p<0.05, n=3)$. This shows the effectiveness of mucuna gum in preparation of microspheres. Since there was no direct relationship between swelling and crosslinking time, the loading efficiencies were not directly related to the crosslinking time except for $3 \mathrm{~h}$ crosslinking. Microspheres formulated and crosslinked for $3 \mathrm{~h}$ had higher mean drug contents and thus higher loading efficiencies at all levels of mucuna gum compared to the drug content of gelatin microspheres (Table I). This was the optimum crosslinking time for the mucuna gum microspheres using glutaraldehyde. The microspheres showed lower swelling than the other batches. Higher degree of swelling weakens secondary bonds in polymers and, thus, the lower degree of swelling in $3 \mathrm{~h}$ crosslinked microspheres may have resulted in stronger attachment of the drug within the mucuna matrix. This is because the drug loading process adopted was remote loading where the matrix is allowed to imbibe the drug from a solution. In all, the remote loading process could be used in formulating mucuna gum microspheres containing glibenclamide. This dosage form would produce an appropriate controlled glibenclamide delivery system that gradually degrades in the body.

Release of glibenclamide in SIF from the various batches of microspheres is graphically represented in Figs. 1a-c, where the percentage amount released is plotted against time. There was a sustained release of the drug in most of the microspheres. However, there was an initial burst effect in almost all the microspheres except the microspheres formulated with $5.0 \%(\mathrm{~m} / \mathrm{V})$ of mucuna gum without crosslinking and that crosslinked for $3 \mathrm{~h}$, microspheres prepared with $7.5 \%(\mathrm{~m} / \mathrm{V})$ of mucuna gum without crosslinking and microspheres prepared with $10.0 \%(\mathrm{~m} / \mathrm{V})$ mucuna gum with $1 \mathrm{~h}$ crosslinking. This is common in microspheres, especially those formulated by the remote loading process. Burst release resulting in biphasic release pattern may be utilized in therapeutic design of dosage forms. It occurs even in microparticles prepared using other established polymers such as poly(D,L-lactide-co-glycolide) $(21,22)$. There may be a lot of peripheral attachment of the drug as a result of expulsion during microsphere drying (elastic contraction as seen in gels) or drug migration as a result of solvent drag during drying. In this case, however, this may be an advantage because it would lead to a high initial blood 

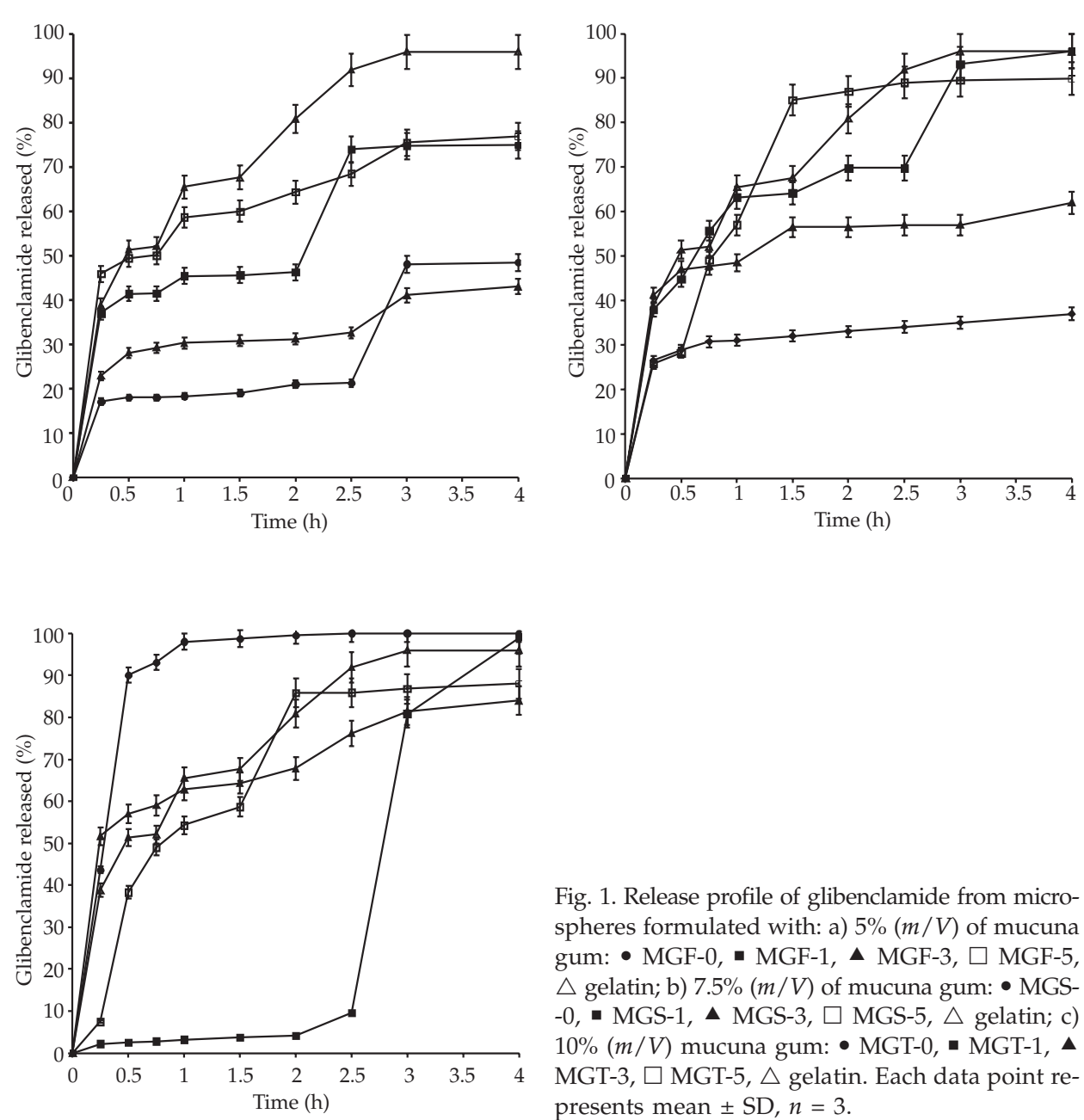

Fig. 1. Release profile of glibenclamide from microspheres formulated with: a) $5 \%(\mathrm{~m} / \mathrm{V})$ of mucuna gum: • MGF-0, - MGF-1, ^ MGF-3, $\square$ MGF-5, $\triangle$ gelatin; b) $7.5 \%(m / V)$ of mucuna gum: $\bullet$ MGS-0 , - MGS-1, $\triangle$ MGS-3, $\square$ MGS-5, $\triangle$ gelatin; c) $10 \%(m / V)$ mucuna gum: • MGT-0, - MGT-1, $\wedge$ MGT-3, $\square$ MGT-5, $\triangle$ gelatin. Each data point represents mean $\pm \mathrm{SD}, n=3$.

concentration of the drug and a gradual release of the remaining drug. In diabetes management, the objective is always to lower the blood sugar level and maintain it at a particular level. This is possible if a bolus dose of the antidiabetic is administered. The bolus dose, when required, will be provided by the initial burst as seen in some of the microsphere formulations in Fig. 1a, and microspheres prepared with $10.0 \%(\mathrm{~m} / \mathrm{V})$ of mucuna gum and crosslinked for 3 and $5 \mathrm{~h}$ (Fig. 1c). Microsphere formulations containing $10.0 \%(\mathrm{~m} / \mathrm{V})$ mucuna gum without crosslinking or crosslinked for $1 \mathrm{~h}$ would not be appropriate for providing initial high blood concentration of gibenclamide as the formulation containing $10.0 \%(m / V)$ mucuna gum without crosslinking emptied all the drug just after about $1 \mathrm{~h}$, while microspheres prepared with $10.0 \%(\mathrm{~m} / \mathrm{V})$ mucuna gum and crosslinked for $1 \mathrm{~h}$ delayed the release of the incorporated drug for $2.5 \mathrm{~h}$. Microspheres 
prepared with 5.0 or $7.5 \%(\mathrm{~m} / \mathrm{V})$ mucuna gum and crosslinked for 1 and $5 \mathrm{~h}$, and those prepared with $10.0 \%(\mathrm{~m} / \mathrm{V})$ mucuna gum and crosslinked for 3 and $5 \mathrm{~h}$ had the tendency to fully sustain the release of glibenclamide. All these microsphere formulations need to be fully optimized using laboratory animals. Mucuna gum possesses bioadhesive properties (11). This is an added advantage since the transit time of the dosage form would be prolonged in the gastrointestinal tract for maximum absorption of the active ingredient. This technique has been utilized in the delivery of some antimicrobial agents for the eradication of Helicobacter pylori (5).

At $5.0 \%(\mathrm{~m} / \mathrm{V})$ mucuna gum concentration, crosslinking did not reduce the release rate of the drug, as the microspheres which were not crosslinked (MGF-0) had lower release than the crosslinked microspheres (Fig. 1a). This may be due to higher gelation in the microspheres prepared without crosslinking, which possessed higher diffusional path length, and the fact that the release of the drug from the crosslinked microspheres proceeded with disintegration of the matrix. However, at the crosslinking time of $3 \mathrm{~h}$ (MGF-3) the ultimate release was lower than that of the microspheres that were not crosslinked (Fig. 1a). Their low release was not due to the low drug content as the batch had loading efficiency of above $80 \%$. It was due to strong attachment of the drug to the polymer matrix. The same trend was observed in microspheres formulated with $7.5 \%(\mathrm{~m} / \mathrm{V})$ mucuna gum (Fig. 1b). In Fig. 1c, it was observed that crosslinking affected the drug release, as the microspheres that were not crosslinked had the fastest and highest release. These microspheres were formulated with $10.0 \%(\mathrm{~m} / \mathrm{V})$ mucuna gum. The later burst effect (af-

Table II. Glibenclamide release kinetic parameters

\begin{tabular}{ccccccc}
\hline & \multicolumn{3}{c}{ Release model } \\
\cline { 2 - 3 } \cline { 5 - 6 } Batch & \multicolumn{2}{c}{ Higuchi } & & \multicolumn{3}{c}{ Ritger-Peppas } \\
\cline { 2 - 3 } \cline { 5 - 6 } MGF-0 & $k_{\mathrm{H}}\left(\% \mathrm{~h}^{-1 / 2}\right)$ & $R^{2}$ & & $k_{\mathrm{RP}}\left(\mathrm{h}^{-1}\right)$ & & $R^{2}$ \\
\hline MGF-1 & 20.763 & 0.6311 & & 0.3919 & 0.0934 & 0.8486 \\
MGF-3 & 29.081 & 0.8070 & & 0.5833 & 0.1096 & 0.9233 \\
MGF-5 & 11.666 & 0.8590 & & 0.6825 & 0.1349 & 0.8781 \\
MGS-0 & 23.244 & 0.9622 & & 0.7511 & 0.1780 & 0.9339 \\
MGS-1 & 6.330 & 0.9746 & & 0.8368 & 0.1049 & 0.9850 \\
MGS-3 & 39.149 & 0.9290 & & 0.5857 & 0.3155 & 0.9271 \\
MGS-5 & 12.898 & 0.9175 & & 0.8136 & 0.1378 & 0.9297 \\
MGT-0 & 49.960 & 0.8424 & & 0.3699 & 1.5264 & 0.7274 \\
MGT-1 & 24.547 & 0.4486 & & 0.9057 & 0.3537 & 0.6855 \\
MGT-3 & 59.113 & 0.5929 & & 0.0483 & 1.0074 & 0.5197 \\
MGT-5 & 22.160 & 0.9669 & & 0.7549 & 0.1690 & 0.9225 \\
Gelatin & 52.254 & 0.8737 & & 0.5047 & 0.8592 & 0.8240 \\
\hline
\end{tabular}

$k_{\mathrm{H}}-$ Higuchi release rate constant

$k_{\mathrm{RP}}-$ Ritger-Peppas release rate constant

$n$ - diffusional exponent 
ter $2.5 \mathrm{~h})$ observed with microspheres formulated with $10.0 \%(\mathrm{~m} / \mathrm{V})$ mucuna gum and crosslinked for $1 \mathrm{~h}$, which is depicted in Fig. 1c could be a result of insufficient time for mutual migration and interaction of the crosslinking agent and the mucuna gum, since the gum concentration was high.

Different mathematical models were used to describe the kinetics of glibenclamide release from the microspheres. The criterion for selecting the most appropriate model was chosen on the basis of a goodness-of-fit test. The release kinetics equation was applied to the whole release period because very few of the microspheres released $100 \%$ of the included drug. The result of the different parameters derivable from the release models is presented in Table II. The values show that with respect to Higuchi's model (17), MGF-5, MGS-0, MGS-1, MGS-3, MGT-3 and gelatin microspheres obeyed the model and thus exhibited diffusion-controlled release. The implication is that at $5.0 \%(\mathrm{~m} / \mathrm{V}) \mathrm{mu}-$ cuna gum concentration, crosslinking the microspheres for $5 \mathrm{~h}$ increased the diffusional tendency of the incorporated drug. Similarly, at $7.5 \%(\mathrm{~m} / \mathrm{V})$ mucuna gum the microspheres diffusionally released up to $3 \mathrm{~h}$ crosslinking. Only $3 \mathrm{~h}$ of crosslinking produced microspheres that had Higuchi diffusional release in $10.0 \%(\mathrm{~m} / \mathrm{V})$ mucuna gum microspheres (MGT-3). In the Ritger-Peppas model (18), all the microspheres formulated, except MGS-5, MGT-1 and MGT-5, had $n$ values lower than 0.43 , and thus exhibited case I Fickian diffusion. Case II transport dominated in MGS-5, MGT-1 and MGT-5 microspheres $(n \geq 0.85)$, indicating a predominantly zero-order release process. However, only MGF-1, MGF-5, MGS-0, MGS-1, MGS-3, MGT-3 and gelatin microspheres could be said to have had straight line plots $\left(R^{2} \geq 0.9\right)$ (Table II), and thus followed the case I transport. These batches may have maintained constant planar surface area for diffusion during the release process. Higher $k_{\mathrm{RP}}$ values indicate higher release rates. As a result, crosslinked microspheres at $5 \%(\mathrm{~m} / \mathrm{V})$ mucuna gum concentration had higher release rates than the microspheres that were not crosslinked. Microspheres formulated with $7.5 \%(\mathrm{~m} / \mathrm{V})$ and $10 \%(m / V)$ mucuna gum without crosslinking (MGS-0 and MGT-0) had higher $k_{\mathrm{RP}}$ values than the crosslinked microspheres, and thus had a higher release rate according to this model. This result, although contrary to that obtained for $5.0 \%(\mathrm{~m} / \mathrm{V})$ mucuna gum microspheres, may be due to higher polymer concentration and low crosslinker concentration. The same quantity of crosslinking agent was used throughout. MGF-0, MGS-0 and MGT-0 possessed different release kinetics, which were different from the expected trend because of the different polymer but constant drug concentration. Therefore, the location of the drug within the polymer matrix affected the release kinetics.

The effect of crosslinking varied and appeared to be affected by polymer concentration (under constant stirring). Overall analysis of the release mechanism indicated that of all the microspheres formulated, $54 \%$ of the total followed the Ritger-Peppas case I transport model while $46 \%$ followed Higuchi's diffusion model.

\section{CONCLUSIONS}

Microspheres with good in vitro properties were formulated with mucuna gum. In vitro evaluation is expected to launch further research into the field of antidiabetic drug delivery considering the functional properties of mucuna gum. 


\section{REFERENCES}

1. J. Patel, P. Bharadia, A. Amin and M. Patel, Formulation optimisation and evaluation of controlled release mucoadhesive microspheres of glipizide for oral delivery using factorial design, Drug Deliv. 4 (2004) 48-53.

2. E. Gavani, V. Sanna, C. Juliano, M. C. Bonferoni and P. Giunchedi, Mucoadhesive vaginal tablets as veterinary delivery system for the controlled release of an antimicrobial drug, acriflavine, AAPS Pharm. Sci. 3 (2002) 1-7.

3. J. Singh and D. H. Robinson, Controlled release of captopril microcapsules: effect of ethyl cellulose viscosity grade on the in vitro dissolution from microcapsules and tabletted microcapsules, J. Microencapsul. 7 (1990) 67-76.

4. M. N. V. Ravi-Kumar, Nano and microparticles as controlled drug delivery devices, J. Pharm. Pharm. Sci. 3 (2000) 234-258.

5. M.-K. Chun, H. Sah and H.-K. Choi, Preparation of mucoadhesive microspheres containing antimicrobial agents for eradication of H. pylori, Int. J. Pharm. 297 (2005) 172-179.

6. F. Delie and M. J. Blanco-Prieto, Polymeric particulates to improve oral bioavailability of peptide drugs, Molecules 10 (2005) 65-80.

7. S. Pamujula, R. A. Graves, V. Kishore and T. K. Mandal, Preparation and in vitro characterization of amifostine biodegradable microcapsules, Eur. J. Pharm. Biopharm. 57 (2004) 213-218.

8. F. Lagarce, P. Renaud, N. Faisant, G. Nicolas, A. Cailleux, J. Richard, P. Menei and J-P. Benoit, Baclofen-loaded microspheres: preparation and efficacy testing in a new rabbit model, Eur. J. Pharm. Biopharm. 59 (2005) 449-459.

9. A. Bernkop-Schnürch, M. Hornof and D. Guggi, Thiolated chitosans, Eur. J. Pharm. Biopharm. 57 (2004) 9-17.

10. J. C. Onweluzo, K. C. Onuoha and Z. A. Obanu, Certain functional properties of gums derived from lesser known tropical legumes (Afzelia africana, Detarium microcarpum and Mucuna flagillepes), Plant Foods Hum. Nutr. 48 (1995) 55-63.

11. A. A. Attama, M. U. Adikwu and N. D. Okoli, Studies on bioadhesive granules. II. Granules formulated with Mucuna flagillepes (mucuna) gum, STP Pharma Sci. 13 (2003) 177-181.

12. A. A. Attama and M. U. Adikwu, Release and permeation properties of jellies formulated with mucuna gum, Plant Prod. Res. J. 2 (1997) 25-31.

13. A. A. Attama, A. I. Chuku, K. N. Muko and M. U. Adikwu, Effects of Veegum on the suspending properties of mucuna gum, Boll. Chim. Farm. 136 (1997) 548-553.

14. O. K. Udeala and U. N. Uwaga, Some emulsifying and suspending properties of a polysaccharide gum from Mucuna flagillepes Papillionaceae, J. Pharm. Pharmacol. 33 (1981) 75-77.

15. J. E. Ojile, M. U. Adikwu and N. D. Okoli, Properties of films prepared from prosopis and mucuna gums, Boll. Chim. Farm. 139 (2000) 190-193.

16. United States Pharmacopoeia 27, National Formulary 22, United States Pharmacopeial Convention, Rockville, 2003, p. 2728.

17. T. Higuchi, Mechanism of sustained action medication. Theoretical analysis of rate of solid drugs dispersed in solid matrices, J. Pharm. Sci. 52 (1963) 1145-1149.

18. P. L. Ritger and N. A. Peppas, A simple equation for description of solute release. I. Fickian and non-Fickian release from non-swellable devices in the form of slabs, spheres, cylinders or discs, J. Control. Rel. 5 (1987) 23-36.

19. R. Rastogi, Y. Sultana, M. Aquil, A. Ali, S. Kumar, K. Chuttani and A. K. Mishra, Alginate microspheres of isoniazid for oral sustained drug delivery, Int. J. Pharm. 334 (2007) 71-77. DOI: 10.1016/ j.ijpharm. 2006.10.024. 
20. N. S. Berchane, K. H. Carson, A. C. Rice-Ficht and M. J. Andrews, Effect of mean diameter and polydispersity of PLG microspheres on drug release: Experiment and theory, Int. J. Pharm. (2007) DOI: 10.1016/j.ijpharm.2006.12.037.

21. H. Zhang and S. Gao, Termozolomide/PLGA microparticles and antitumor activity against Glioma C6 cancer cells in vitro, Int. J. Pharm. 329 (2007) 122-128; DOI: 10.1016/j.ijpharm.2006.08.027.

22. M.-K. Yeh, J.-L. Chen and Z.-Y. Chang, The preparation of sustained release erythropoietin microparticle, J. Microencapsul. 24 (2007) 82-93; DOI: 10.1080/02652040601058533.

\title{
$S A \check{Z} E T A K$
}

\section{Mikrosfere s mukuna gumom za peroralnu primjenu glibenklamida: In vitro ispitivanje}

\author{
ANTHONY AMAECHI ATTAMA i OBICHUKWU J. NWABUNZE
}

U radu je opisana priprava mikrosfera s mukuna gumom za peroralnu primjenu glibenklamida. Pri izradi mikrosfera varirana je koncentracija polimera i vrijeme umrežavanja, a brzina je bila konstantna. Mikrosfere su zatim punjene glibenklamidom metodom odvojenog punjenja. Pripravljenim mikrosferama procijenjena je veličina čestica, iskorištenje, učinkovitost punjenja i sposobnost bubrenja. In vitro oslobađanje glibenklamida iz mikrosfera praćeno je u simuliranoj intestinalnoj tekućini (SIF, pH 7.4). Za određivanje mehanizma oslobađanja ispitana su dva modela. Sve mikrosfere su imale dobru sposobnost bubrenja u destiliranoj vodi. Optimalno produljeno oslobađanje glibenklamida postignuto je iz mikrosfera priređenih s $5 \%(\mathrm{~m} / \mathrm{V})$ mukuna gume, uz vrijeme umrežavanja 5 h. Ljekovita tvar se najsporije oslobađala iz mikrosfera priređenih s $10 \%(\mathrm{~m} / \mathrm{V})$ mukuna gume, uz vrijeme umrežavanja $1 \mathrm{~h}$, dok se najbrže oslobađala iz mikrosfera s $10 \%(\mathrm{~m} / \mathrm{V})$ gume, bez umrežavanja. Nekoliko mehanizama oslobađanja uključeno je u otpuštanje ljekovite tvari iz mikrosfera. Međutim, Ritger-Peppasov transportni model I opisuje proces oslobađanja u 54\% slučajeva, što znači da mikrosfere glibenklamida s mukuna gumom predstavljaju pouzdan sustav za peroralnu primjenu te ljekovite tvari.

Ključne riječi: mukuna guma, mikrosfere, glibenklamid, in vitro oslobađanje, peroralna primjena

Drug Delivery Research Unit, Department of Pharmaceutics, Faculty of Pharmaceutical Sciences University of Nigeria, Nsukka 410001 Nigeria 